\title{
НОВІ ІННОВАЦІЙНІ ТЕХНОЛОГІЇ ТА ШЛЯХИ ПОЛІПШЕННЯ НАВЧАЛЬНОГО ПРОЦЕСУ ЗІ СПЕЦІАЛЬНОСТІ "НЕВРОЛОГІЯ"
}

\author{
В. А. Гриб \\ Івано-Франківський національний медичний університет
NEW INNOVATIVE TECHNOLOGIES AND WAYS TO IMPROVE THE EDUCATIONAL PROCESS OF SPECIALTY "NEUROLOGY"

\author{
Ivano-Frankivsk National Medical University
}

\begin{abstract}
У роботі узагальнено досвід кафедри неврології ІФНМУ впровадження і удосконалення інноваційних технологій при використанні інтерактивних методів навчання на всіх етапах навчального процесу з вивчення спеціальності студентами медичного факультету. На етапі визначення кінцевого рівня знань використовуються тестування, вирішення кейсзавдань, ігрові і неігрові методи модельованого навчання, а якість отриманих знань оцінюється поточним та підсумковим модульним контролем.
\end{abstract}

The experience of the Ivano-Frankivsk National Medical University Department of Neurology of the innovative technologies implementation and improvement of used interactive teaching methods at all stages of the students' learning process of studying specialty in medical faculty is presented. At the stage of determining the final level of knowledge the test case-solving tasks, gaming and non-fiction techniques simulated training are used, and quality of the knowledge is assessed with current and final module control.

Вступ. Інтеграція України в Свропу передбачає реформування вищої освіти та входження в Європейський освітній простір. Цей процес вимагає нових підходів до організації навчального процесу у вищих навчальних закладах, що було задекларовано Україною у підписанні Болонської конвенції [1, 2]. Одним із напрямків для створення комфортних умов навчального процесу є використання інноваційних технологій і в першу чергу інтерактивних методів навчання [3, 4], які є особливою системою правил організації продуктивної взаємодії між собою тих, хто навчається, $\mathrm{i}$ тих, хто навчає [5]. Цей метод передбачає як підвищення якості викладання теоретичного курсу з використанням сучасних технологій: проблемні лекції, лекції майстер-клас, лекції прес-конференції [6], так і практичної підготовки, де порядз традиційними підходами - робота студента 3 хворими, відшліфування ним майстерності визначення патологічних симптомів та ознак - широко застосовують технології ситуаційного навчання (кейс-метод, імітацію рольових ігор) $[4,6]$. Не менш важливою є правильна організація самостійної роботи студента (СРС) з вивчення і оволодіння окремими позааудиторними темами кредиту із залученням низки інноваційних технологій: використання інтернет-мережі, електронних варіантів наробок кафедри, кафедр інших вузів та сприяння до участі студентів в науково-дослідницькій роботі.

Для контролю за отриманими знаннями та вміннями використовують тестову і рейтингову системи оцінювання якості теоретичних знань, визначаючи як поточний, так і кінцевий рівень на кожному занятті, а також підсумково-модульний контроль (ПМК). При цьому оцінюють роботу студента біля ліжка хворого, виконання ним діагностичних мануальних прийомів, уміння встановити топічний та кінцевий діагноз і визначити алгоритм лікування. Отже, одним із важливих напрямків інтерактивного навчального процесу $є$ використання сучасних технічних засобів, необхідних для найбільш ефективного сприйняття та засвоєння матеріалу [7]. Тому метою даної роботи було систематизувати та узагальнити досвід інтерактивного, інноваційного підходу у навчанні студентів медичного факультету з неврології та продемонструвати його роль у вдосконаленні засвоєння ними знань і вмінь зі спеціальності.

Основна частина. У перекладі 3 грецької мови "inovatio" означає оновлення, новизну, зміну. Найпоширенішим $є$ визначення цього слова американського вченого К. Роджера, який стверджує, що “новизна це ідея, що є для конкретної особи об'єктивно новою і не має значення, ідея є об'єктивно новою чи ні, ми визначаємо їі в часі, який минув 3 моменту їі відкриття 
або першого використання”. Головна мета інноваційної освіти - забезпечення та розвиток творчого потенціалу людини, а також її всебічний розвиток.

Цим умовам відповідає використання інтерактивних методів навчання. При цьому, по-перше, важливою $є$ активна взаємодія учасників освітнього процесу, під якою розуміють стосунки між людьми, коли вони в процесі вирішення спільних завдань, впливаючи один на одного, доповнюючи один одного, успішно вирішують ці завдання. По-друге, використання інтерактивних методів навчання передбачає таку логіку та послідовність навчальної діяльності: мотивація; формування нового досвіду; його усвідомлення через застосування; рефлексія. По-третє, інтерактивні методи характеризує робота в малих групах на основі кооперації та співпраці. По-четверте, інтерактивні методи базуються на ігрових та неігрових формах навчання.

Ігрові - включають імітаційні та неімітаційні методи навчання:

- до імітаційних методів належать: а) рольові ігри; б) навчально-ділові ігри, (операційні та імітаційні);

- неімітаційні ігрові методи навчання представлені: а) дослідницькими діловими іграми; б) кейс-методами; в) проектними методами; г) організаційно-діяльнісними іграми (організаційно-розумові, моделюючі, проектні ігри); д) аналізом конкретних ситуацій (аналіз мікроситуацій, аналіз ситуацій-ілюстрацій, аналіз ситуацій-проблем, розбір і обговорення конкретного матеріалу вивчення передового досвіду і обмін знаннями); е) тренінговими методами (тренінг-сенситивності, комунікативний тренінг, відеотренінг).

Неігрові інтерактивні методи навчання представлені методами діалогічної взаємодії: дебати, диспути, відкриті форуми, різні види дискусій (“круглий стіл”, проблемна дискусія, експрес-дискусія, “Акваріум", “Ліберальний клуб”, текстова дискусія) [8]. Методи активного навчання можуть використовуватися на різних етапах навчального процесу:

І етап - первинне оволодіння знаннями. Це можуть бути проблемна лекція, евристична бесіда, навчальна дискусія та ін.

II етап - контроль знань (закріплення). Можуть бути використані такі методи, як колективна розумова діяльність, тестування.

III етап - формування професійних умінь, навичок на основі знань і розвиток клінічного мислення, можливе використання модельованого навчання, ігрові й неігрові методи.

Інтерактивні методи відіграють важливе значення на всіх етапах навчання. Проте при вивченні невро- логії особливого значення вони набувають на етапі формування професійних умінь та навичок у процесі курації хворого. Результатом цього етапу є вироблення клінічного мислення: вміння формування діагнозу, алгоритму лікування і профілактики захворювання [6, 9].

На кафедрі неврології ІФНМУ навчання студентів медичного факультету здійснюється за типовою програмою з дисципліни “Неврологія" (2007 р.) зі змінами, внесеними наказом МОЗ України від 08.07.2010 p. та Додатком змін, розробленим співробітниками опорної кафедри неврології ХНМУ (К., 2012 р.). На основі цих документів кафедрою розроблена робоча програма, згідно $з$ якою поспіль 7-8 семестрів навчання студенти вивчають та засвоюють два модулі: № 1 (загальна неврологія) та № 2 (спеціальна неврологія), або 5,5 кредитів ECTS, які складають 165 годин, в т. ч. аудиторних 110 (20 лекцій та 90 практичних занять) та 55 годин СРС. Програмою передбачено два ПМК, які проводяться на останніх заняттях обох кредитних термінів. Вивчення курсу "Неврологія" за розкладом семестру університету, як і інших клінічних дисциплін, здійснюється у спарених парах (4 год) з вивченням двох тем. Курацію хворих розділено на дві окремі теми: курація хворого та захист історії хвороби. Обробку отриманого матеріалу під час курації та написання історії хвороби студенти здійснюють як вид СРС. При курації хворого вони демонструють вміння фізикального обстеження хворого, визначення окремих синдромів, інтерпретацію даних лабораторних та інструментальних методів дослідження. Диференційний діагноз та остаточний клінічний діагноз студенти обгрунтовують під час захисту історії хвороби, демонструючи знання алгоритму лікування з елементами фармакокінетики ти фармакогнозії даного захворювання. Крім того, студент дає відповіді на 2-3 запитання з етіопатогенезу, клініки, лікування та профілактики захворювання. Інноваційними нововведеннями під час захисту історії хвороби є вимога складання кожним студентом інтегрально-графічних схем 3 діагностики даного захворювання та задач з топічної діагностики хворих з атактичним синдромом, при нижньому та верхньому парапарезах, гемі- та монопарезах, створення схем кірково-ядерного та кірково-спинномозкового шляхів та структур екстрапірамідної системи з вказанням рівня їх ураження курованого пацієнта.

Теоретична підготовка студентів здійснюється під час лекцій, практичних занять та самостійної роботи з вивчення окремих тем. При проведенні лекцій нами 
широко застосовуються методи “інформаційного повідомлення”: аудіовізуальні презентації, відеофільми, графіки, інтегральні схеми патогенезу та топічної діагностики різних рівнів ураження нервової системи, відео- та мультимедійні презентації з демонстрацією дослідження неврологічного статусу хворих з різною патологією. Поєднання коментарів лектора з відеоінформацією та анімацією значно мотивує увагу слухачів до викладання матеріалу за темою. Досить цінним під час лекції є презентація відео чи мультимедійних преференцій, діагностики та лікування окремих пацієнтів 3 практики лектора. Подальше засвоєння лекційного матеріалу проходить у вигляді співбесіди у діалоговому режимі (питання відповідь). Таким чином, при викладанні теоретичного матеріалу кафедра переважно використовує дидактичні засоби навчання, варіантом якого є проблемна лекція, що створює певні ситуації і залучає слухачів до їх вирішення. Така методика, за даними анкетування студентів, при складанні ПМК дала їм можливість швидше і якісніше засвоїти тему, а рівень збережених знань становив 65-75 \%, тоді як при традиційному викладенні-25-30 \%. Цьому також сприяло надання студентам лекційних матеріалів на електронних носіях, що уможливлює в будь-який час протягом 15-20 хв оновити в пам' яті надану інформацію. Тоді як паперові носії без унаочнення теми вимагають для повторення матеріалу до однієї години.

Засвоєння теоретичного матеріалу на практичних заняттях проводиться також із залученням інтерактивних методик: імітаційних ділових ігор, різних видів дискусій, семінарів-тренінгів, а за допомогою кейсметоду (активного проблемно-ситуаційного аналізу) - вирішенням конкретних завдань-ситуацій. Не менш важливим на початку заняття $є$ експрес-метод тестового контролю засвоєння теми в домашніх умовах шляхом вирішення тестів, кейс-завдань кожним студентом. Кафедрою розроблено 85 кейс-ситуаційних завдань 3 різних тем загальної та спеціальної неврології, а також використовуються ситуаційні завдання комп'ютерного контролю, розв'язування блоку завдань 3 неврології КРОК-2. Крім цього, засвоєння теми відбувається шляхом дискусії і відповідей на окремі запитання, висвітлених у методичних вказівках для студентів. Після аудиторного засвоєння теоретичних основ теми наступним етапом $є$ засвоєння практичних навичок біля ліжка тематичного хворого. Як правило, група студентів викладачем ділиться на 3-5 підгруп по 2-3 студенти, які самостійно проводять збір анамнезу та фізикальне загальнотерапевтичне обстеження. Дослідження неврологічного статусу проводиться за допомогою та під контролем викладача. Важливою умовою оволодіння студентами теоретичними знаннями і практичними навиками є високий рівень кваліфікації викладача, який $\epsilon$ особистістю всебічно розвинутою, професійно володіє неврологічною практикою, науково-культурним світоглядом, комунікативними та ораторськими здібностями.

Досить важливим у структурі кредитно-модульної системи навчання є оцінка якості отриманих знань та вмінь при проведенні поточного контролю на практичних заняттях та кінцевого - на ПМК. 3 цією метою етапи проведення практичних занять та система оцінки якості на кафедрі уніфіковані. Кількість балів на кожне заняття $є$ сумою від оцінки виконання трьох завдань: тестовий контроль, практичних навичок (практичний тренінг, рішення ситуаційних завдань, виконання мануальних прийомів визначення окремих симптомів та вміння інтерпретувати результати лабораторно-інструментальних методів дослідження), усна відповідь. Максимальна кількість балів за поточну діяльність студента складає 120. Студент допускається до ПМК 1-го модуля при умові виконання вимог навчальної програми та в разі, якщо він набрав не менше 56 балів, до ПМК 2-го модуля - 54 бали. Крім цього передбачено оцінку індивідуальної самостійної роботи студента: 1 бал - участь у роботі СНГ, та 1 бал за доповідь на засіданні гуртка, 1 бал нараховується студенту за кожне чергування в клініці.

ПМК є завершальним етапом оцінювання знань. Він проводиться за спеціально розробленим протоколом із фіксованою кількістю балів, максимум - 80 балів, 3 яких: тести в кількості 20 (0-20 балів); 2 практичні навички, кожна - по 15 балів; 2 усних питання, кожне з яких оцінюється 0-15 балів.

Впровадження і удосконалення інноваційних методів при кредитно-модульній системі навчання 3 неврології дало певні позитивні зміни в показниках успішності. Так, якщо в перший навчальний рік сумарний бал ПМК складав 106-119 у 25,7 \%; 120-149 - у 49,8 \%; 150-169 - у 18,7 \%; а 170 балів і більше було всього в 5,8 \%, то в останній рік питома вага найнижчої оцінки (106-119) була дещо меншою і складала 20,8 \% та значно зріс відсоток студентів з балом 150-169 до 33,2 \%, хоча не відзначено змін 3 боку студентів із високим рівнем знань, тобто балом 170 і більше (6,1%). Слід відмітити зменшення кількості студентів, котрі були не допущені до складання ПМК внаслідок невиконання навчального плану, з 14 до $9 \%$. Банк необхідних практичних навичок для модуля 1 складає 25, для модуля $2-11$. В ос- 
танній рік при аналізі вміння виконання практичних навичок відзначено у всіх студентів значне покращення їх техніки, що пов'язано, вірогідно, зі зростанням педагогічної та спеціальної майстерності викладацького складу, а також застосуванням інноваційних методик у навчальному процесі. Цьому сприяє демонстрація (майстер-клас) виконання практичних навичок досвідченим доцентом перед кожним 3 п’яти змістових модулів для всіх викладачів, що створює і уніфікує єдину технологію навчання мануальної техніки виконання навички, з наступним відпрацюванням іiі викладачами поспіль навчання 3 кожним студентом.

Таким чином, вивчення спеціальності “Неврологія”

\section{Література}

1. Суліма Є. Невідкладні завдання системи вищої освіти на новому етапі Болонського процесу / С. Суліма // Вища школа. - 2010. - № 1.- С. 5-13.

2. Ковальчук Л. Я. Новітні шляхи вдосконалення підготовки фахівців у Тернопільському державному медичному університеті імені І. Я. Горбачевського / Л. Я. Ковальчук // Медична освіта. - 2010. - № 2. - С. 27-30.

3. Dent. J. R. A practical guide for medical teachers / J. R. Dent, R. M. Harden. - Churchill Livengstore Elsevier: Edinburgh, London, New York, Oxford, Philadelphia, St. Louis, Sydney, Toronto, 2009. $-435 \mathrm{p}$.

4. Удосконалення засвоєння практичних навичок і методик студентами та лікарями-інтернами - важлива складова кадрової перебудови первинної ланки медичної допомоги населенню України / О. П. Волосовець, Ю. С. П'ятницький, I. С. Вітенко [та ін.] // Медична освіта. - 2012. - № 3. C. 5-7.

5. Aronson L. Twelve tips for teaching reflection at all level of medical education / L. Aronson // Med. Teacher. - 2011. Vol.33(3).-P.200-205.

6. Використання інтерактивних методів навчання при відповідно до провідних засад Болонського процесу заслуговує на подальше вдосконалення, що суттєво сприяє підвищенню якості отриманих теоретичних знань і необхідних практичних навичок студентами та наближає процес навчання до вирішення актуальних проблем і вимог сучасності.

Висновок. Інтерактивні, інноваційні методи підвищують ефективність та результативність навчання за їх використання на етапах навчального процесу. Особливе значення вони набирають при роботі студентів з хворими і формуванні професійних вмінь та навичок, для чого необхідно систематизувати, уніфікувати техніку і послідовність мануального виконання практичних навичок.

вивченні основ внутрішньої медицини / О. С. Хухліна, Л. В. Каньовська, О. С. Воєвідка [та ін.] // Впровадження нових технологій за кредитно-модульної системи організації навчального процесу у ВМ(Ф)НЗ III-IV рівнів акредитації : матеріали Всеукр. навч.-наук. конф., присвяченої 55-річчю Тернопільського державного медичного університету імені І. Я. Горбачевського (м. Тернопіль, 26-27 квітня 2012 р.).-Тернопіль : Укрмедкнига, 2012.-С. 415-416.

7. Волосовець А. О. Використання відеопрезентацій у навчальному процесі на кафедрі неврології / А. О. Волосовець // Розвиток наукових досліджень : матеріали VII наук.практ. конф. (м. Полтава, 28-30 листопада 2011 р.). - Полтава : Вид-во “Інтер-Графіка", 2011.- Т. 6. -С. 32-33.

8. Еримбетова С. Использование интерактивных технологий обучения в процессе творческого развития учащегося / С. Еримбетова, А. Г. Маджуга, Б. Ахметжан // Вестник высшей школы “Альма-Матер”. - 2003. - № 11.-С. 48-52.

9. Solomon P. Student perspectives on patient educators as facilitators of interprofessional education / P. Solomon // Med.Teacher. -2011. - Vol. 33, № 10-P. 851-853. 